\title{
The Type b Capsulation Locus of Haemophilus influenzae: Map Location and Size
}

\author{
By B. W. CATLIN \\ Department of Microbiology, Medical College of Wisconsin, \\ Milwaukee, Wisconsin 53233, U.S.A. \\ AND J. W. BENDLER, III AND S. H. GOODGAL \\ Department of Microbiology, School of Medicine, University of Pennsylvania, \\ Philadelphia, Pennsylvania 19104, U.S.A.
}

(Accepted for publication 24 November 197I)

SUMMARY

Capsulation of Haemophilus influenzae was investigated by genetic transformation with high-molecular-weight deoxyribonucleic acid. The DNA was extracted from a capsulated antibiotic-resistant strain of $H$. influenzae RD which had received the type b capsulation locus ( $c a p b$ ) by transformation. A non-capsulated polyauxotrophic derivative of strain RD was used as recipient under conditions which permitted the Cap b transformants (assayed as iridescent colonies) to initiate multiplication promptly. The position of cap $b$ on the $H$. influenzae chromosome map was established by use of chemically defined agar media selective for transformants which had received pairs of linked markers. The cap $b$ locus lies between leucine and biotin loci, and shows about $80 \%$ linkage to the bio-I 50 marker. The size of the DNA segment required for $\mathrm{Cap} b$ transformation was found by physical methods to be about 33 million daltons.

\section{INTRODUCTION}

Capsulation is the only property of Haemophilus influenzae which is known to contribute directly to its pathogenicity for man (Leidy, Hahn, Zamenhof \& Alexander, 1960; Turk \& May, 1967). Of the six serological types of capsulated $H$. influenzae, type $\mathrm{b}$ is the most frequent cause of life-threatening disease. The type $b$ capsule is composed of polyribophosphate (Rosenberg \& Zamenhof, 196r). The biosynthesis of this polymer and the genetic lesions which affect the pathway have not been elucidated. As a basis for such investigations it is important to establish the chromosomal location and linkage relations of the type $b$ capsulation locus.

The type specific capsules of Haemophilus influenzae were first demonstrated by Pittman (I93I). She observed that cultures of these capsulated bacteria form colonies which are highly iridescent when viewed by oblique transmitted light. Such cultures often showed in addition a few non-iridescent rough-surfaced colonies (R) composed of non-capsulated bacteria, which were recognized as stable genetic variants (Pittman, I93I). Alexander \& Leidy (195I) utilized capsulation as a genetic marker to demonstrate the occurrence of transformation in $H$. influenzae. Non-capsulated $\mathrm{R}$ variants derived from each of the capsular serotypes were examined for their ability to be transformed by deoxyribonucleic acid (DNA) preparations extracted from capsulated donor bacteria. Strain RD (selected from a capsulated type d) proved to be the most dependable recipient, being transformed to capsular type $a, b$, c, d, e or f, according to the capsular type of the DNA donor (Alexander, Leidy \& Hahn, 
I954). As only a small fraction of cells of these recipient populations became competent to take up DNA and be transformed, the capsulated bacteria were detected only after the Levinthal broth cultures of DNA-treated bacteria were incubated for 24 to $48 \mathrm{~h}$ in the presence of anti- $R$ serum. The untransformed $R$ bacteria were agglutinated, and the capsulated transformants multiplied in the supernatant broth where they were detected either microscopically by the capsular swelling reaction or macroscopically by the appearance of iridescent colonies on Levinthal agar subcultures (Alexander \& Leidy, 195I). Methods subsequently devised have raised the level of competence of strain RD so that routinely over I $\%$ transformation of streptomycin resistance can be obtained. This fraction of competent cells made it practical to study capsular transformation at the cellular level by immunofluorescence microscopy. Type $\mathrm{b}$ antigen was detected $40 \mathrm{~min}$ after adding the transforming DNA to a population of strain RD whose doubling time was about 50 min (Catlin \& Tartagni, 1969).

The genetic map of a large region of the chromosome of Haemophilus influenzae has been defined by transformation with high-molecular-weight DNA (Michalka \& Goodgal, 1969). Knowledge of the linkage relations of 16 genetic markers (Michalka \& Goodgal, I969; and unpublished findings) provided an approach to mapping the capsulation loci. The probability of recovering capsulated transformants (unselected marker) is greatly increased by selecting for transformed bacteria that have received linked markers which are located on either side of the unselected marker. Colonies growing on the selective agar media are inspected for the iridescence typical of capsulated transformants. Examination of ten classes of linked double transformants established that the loci for type $\mathrm{b}$ capsular antigen production $(\mathrm{cap} b)$ and for biotin synthesis are closely linked. Physical methods were used to determine that the minimum size of the DNA fragment required for eliciting Cap $b$ transformation is about 33 million daltons.

\section{METHODS}

Strains and abbreviations. All bacteria used in this study were typical Haemophilus influenzae: Gram-negative rods having requirements for haemin and nicotinamide adenine dinucleotide (NAD). The polyauxotrophic strain A8 (Michalka \& Goodgal, 1969) has additional growth requirements for alanine, hypoxanthine, valine, lysine, leucine, biotin, proline and tryptophan. Abbreviations for this phenotype are: $\mathrm{Ala}^{-} \mathrm{Hyp}^{-} \mathrm{Val}^{-} \mathrm{Lys}^{-} \mathrm{Leu}^{-}$ Bio-Pro-Trp- $^{-}$. The following auxotrophic markers mapped by Michalka \& Goodgal (I969), were used in the present work: ala-146, val-238, lys-176, leu-44, bio-I 5o, pro-14 and trp-235. In addition, strain A8 is resistant to streptomycin (Str-r), and susceptible to the other antibacterial agents listed below.

Strain RD (a gift from Grace Leidy) is prototrophic, i.e. $\mathrm{Ala}^{+} \mathrm{Hyp}^{+} \mathrm{Val}^{+} \mathrm{Lys}^{+} \mathrm{Leu}^{-} \mathrm{Bio}^{+}$ Pro+ ${ }^{+} \mathrm{Trp}^{+}$. The capacity to synthesize type $b$ capsular antigen ( $\mathrm{Cap} b$ ) was introduced initially into strain RD by transformation with DNA from a clinical isolate. DNA from this transformant (RD(b)FA, Catlin \& Tartagni, 1969) was used subsequently to transfer the cap $b$ locus into Haemophilus influenzae MAP. MAP (multiple antibiotic-resistant prototroph) is a derivative of strain $\mathrm{RD}(\mathrm{S} 2)$, which carries the $\mathrm{S} 2$ prophage and eight antibiotic resistance markers(introduced by transformation): streptomycin, kanamycin, spectinomycin, viomycin, streptovaricin (Sva-r), novobiocin (Nov-r), erythromycin (Ery-r) and nalidixic acid (Nal-r).

Stock cultures of all bacteria were preserved at $-60^{\circ}$.

Media. The defined medium MIc described by Herriott, Meyer, Vogt \& Modan (1970) for growth of Haemophilus influenzae strain RD was modified to provide a solid medium for rapid colony formation by strain A8 (which was not adapted for growth on the defined 
Table r. Composition of defined medium for Haemophilus influenzae

\begin{tabular}{|c|c|c|c|c|c|}
\hline Component & $\begin{array}{c}\text { Stock } \\
\text { solution* }\end{array}$ & $\begin{array}{c}\text { Final } \\
\text { concn } \\
(\mu \mathrm{g} / \mathrm{ml})\end{array}$ & Component & $\begin{array}{c}\text { Stock } \\
\text { solution* }\end{array}$ & $\begin{array}{r}\text { Final } \\
\text { concn } \\
(\mu \mathrm{g} / \mathrm{ml})\end{array}$ \\
\hline L-Aspartic acid & (I) & 500 & $\mathrm{NaOH}$ to give $\mathrm{pH} 7 \cdot 2$ & $5 \mathrm{~N}$ & - \\
\hline L-Glutamic acid & (I) & I 300 & $\mathrm{NaHCO}_{3}$ & $84 \mathrm{mg} / \mathrm{ml}$ & 84 \\
\hline $\mathrm{NaCl}$ & ( $\mathrm{I})$ & 5800 & Glutathione (reduced) & $3 \mathrm{mg} / \mathrm{ml}$ & 30 \\
\hline $\mathrm{K}_{2} \mathrm{SO}_{4}$ & (I) & I OOO & L-Isoleucine & $3 \mathrm{mg} / \mathrm{ml}$ & 30 \\
\hline $\mathrm{MgCl}_{2}$ & ( & 200 & Haemin & (6) & IO \\
\hline Ethylenediaminetetraacetate & (I) & 4 & L-Histidine hydrochloride & (6) & IO \\
\hline $\mathrm{NH}_{4} \mathrm{Cl}$ & (I) & 220 & $2,2^{\prime}, 2^{\prime \prime}$-nitrilotriethanol & (6) & 400 \\
\hline L-Arginine hydrochloride & (2a) & 300 & Nicotinamide adenine & (7) & 4 \\
\hline Glycine & (2a) & 30 & dinucleotide & & \\
\hline L-Methionine & (2a) & 100 & Thiamine hydrochloride & (7) & 4 \\
\hline L-Serine & (2a) & 100 & Calcium pantothenate & (7) & 4 \\
\hline L-Tyrosine & (2c) & 200 & L-Alanine & $10 \mathrm{mg} / \mathrm{ml}$ & 100 \\
\hline Tween 80 & (3) & 20 & L-Valine & $6 \mathrm{mg} / \mathrm{ml}$ & 60 \\
\hline Sodium lactate & $(3 \dagger)$ & I 000 & L-Lysine hydrochloride & $10 \mathrm{mg} / \mathrm{ml}$ & 100 \\
\hline Glycerol & (3) & 3000 & L-Leucine & $15 \mathrm{mg} / \mathrm{ml}$ & I 50 \\
\hline Uracil & $(4 \dagger)$ & 75 & L-Proline & $10 \mathrm{mg} / \mathrm{ml}$ & 100 \\
\hline Hypoxanthine & $(4 \dagger)$ & 30 & L-Tryptophan & IO $\mathrm{mg} / \mathrm{ml}$ & 100 \\
\hline Inosine & $(5 \dagger)$ & 100 & $(+)$ Biotin & saturated & $<\mathrm{I}$ \\
\hline $\mathrm{K}_{2} \mathrm{HPO}_{4}$ & (5) & 3480 & Agar (double strength in & 一 & 10000 \\
\hline $\mathrm{KH}_{2} \mathrm{PO}_{4}$ & (5) & 2720 & water) & & \\
\hline L-Cysteine & 一 & 100 & $\mathrm{CaCl}_{2} \cdot 2 \mathrm{H}_{2} \mathrm{O}$ & $37 \mathrm{mg} / \mathrm{ml}$ & 37 \\
\hline
\end{tabular}

* Numbers in parenthesis refer to the solutions used for medium MIc, as given by Herriott et al. (1970).

$\dagger$ Indicates that the concentration used here differs from that of MIc.

medium used by Michalka \& Goodgal, 1969). The components are listed in Table I in the order in which they are mixed to produce the complete medium. Stock solutions I (without $\mathrm{CaCl}_{2}$ ); 2c, 6 and 7 were prepared as described (Herriott et al. 1970). Solution 2a (without lysine) was made up in glass-distilled water as were the other solutions with the exception of tyrosine, cysteine and the mixture of hypoxanthine and uracil (dissolved in $\mathrm{HCl}$ ) and biotin (a saturated solution in 50\% (v/v) ethanol, Michalka \& Goodgal, 1969). Solutions 3, 4 and 5 were made up as described (Herriott et al. 1970) except for omissions or modified concentrations as indicated in Table I. The agar (Purified grade of Difco) and solutions I, 3 and 6 were sterilized by heat (Herriott et al. 1970). Other solutions were sterilized by filtration (Millipore $0.45 \mu$ porosity membranes). The cysteine ( $100 \mathrm{mg} / 1$ of medium, dissolved in $5 \mathrm{ml}$ I $\mathrm{N}-\mathrm{HCl}$ when needed) was added directly to the mixture of stock solutions. Separate solutions were made of the biotin and six amino acids listed last (Table I) so that they might be individually added or omitted. The calcium was added to the melted agar just before the agar was combined with the remainder of the medium. The medium was distributed into Falcon plastic Petri dishes; approximately $20 \mathrm{ml}$ was added to each $100 \times 15 \mathrm{~mm}$. diam. dish in order to obtain a uniform depth of medium needed for standardizing observations of colonial iridescence.

Defined medium was made up in two different laboratories using different lots of chemicals, obtained in some cases from different suppliers (listed in Michalka \& Goodgal, 1969; or the best grade obtainable from Calbiochem, Los Angeles, and from the Fisher Scientific Co., Fair Lawn, New Jersey). Only one difficulty was encountered due to such differences. The haemin solution 6 was unstable when prepared with 'Certified Triethanolamine' from one source. The same haemin (Nutritional Biochemicals Corp., Cleveland, Ohio) when dissolved with the aid of a different triethanolamine $\left(2,2^{\prime}, 2^{\prime \prime}\right.$-nitrilotriethanol, Mallinckrodt 
Chemical Works, St. Louis, Missouri) was effective and stable when stored at $-15^{\circ}$ until used.

The fluid used for washing and diluting the transformed bacteria was the neutralized solution of the first $2 \mathrm{I}$ components listed in Table $\mathrm{I}$, together with the $\mathrm{CaCl}_{2}$ (40 $\mathrm{ml}$ of this mixture diluted to $100 \mathrm{ml}$ with water).

Several infusion media were used. The broth for competence development was brain heart infusion (BHI) (BBL or Difco products were used at various times) freshly made and supplemented with the growth factors (given as final concentrations): NAD $(0.5 \mu \mathrm{g} / \mathrm{ml}$ ) and either haemin (10 $\mu \mathrm{g} / \mathrm{ml}$ ) or Levinthal stock $2 \%(\mathrm{v} / \mathrm{v})$ of the sheep blood extract (Catlin, 1970). The composition of Levinthal agar with $5 \mu \mathrm{g} / \mathrm{ml}$ and $\mathrm{I} \%(\mathrm{v} / \mathrm{v})$ final concentration of the blood extract, was described previously (Catlin, 1970). This same medium, except for omission of agar, was Levinthal broth.

Antibiotics. Streptovaricin (a gift from the Upjohn Co., Kalamazoo, Michigan) was dissolved in $50 \%(\mathrm{v} / \mathrm{v})$ ethanol to make a stock solution containing $10 \mathrm{mg} / \mathrm{ml}$. and used at a final concentration of $5 \mu \mathrm{g} / \mathrm{ml}$. Novobiocin (Cathomycin Sodium, Merck, Sharp \& Dohme, West Point, Pennsylvania) dissolved in water, was used in defined agar at a final concentration of $10 \mu \mathrm{g} / \mathrm{ml}$, and in Levinthal agar at a final concentration of $5 \mu \mathrm{g} / \mathrm{ml}$. Erythromycin (Erythrocin Lactobionate, Abbott, Chicago, Illinois), dissolved in water was used at a final concentration of $15 \mu \mathrm{g} / \mathrm{ml}$. Nalidixic acid (a gift of the Sterling-Winthrop Research Institute Rensselaer, New York) was dissolved in $0 \cdot$ I N-NaOH (Michalka \& Goodgal, 1969) and used at a final concentration of $3.0 \mu \mathrm{g} / \mathrm{ml}$.

High molecular weight DNA. DNA was extracted from capsulated bacteria which had received the cap $b$ locus by transformation. The identity of the capsules was ascertained by the capsular swelling reaction in the presence of specific type b antibody (Catlin \& Tartagni, I969). To assure maximum homogeneity of the population, serial subcultures were made from isolated iridescent colonies and the inocula for broth cultures were taken from young colonies observed at $\times 9$ magnification to be homogeneously iridescent. Cultures incubated at $37^{\circ}$ with shaking for 5 to $6 \mathrm{~h}$ were harvested by centrifugation at $4^{\circ}$. The bacteria were resuspended in a solution of $0.05 \mathrm{M}$-sodium ethylenediaminetetraactate $+0.15 \mathrm{M}-\mathrm{NaCl}$ $(\mathrm{pH} 8)$ to give a density of about $\mathrm{I}$ to $2 \times 10^{10} \mathrm{bacteria} / \mathrm{ml}$, and were again centrifuged. Subsequent steps of washing and lysing the bacteria and deproteinizing the DNA followed the method of Berns \& Thomas (I965) essentially as described by Michalka \& Goodgal (I969) for isolation of high-molecular-weight DNA; similar precautions were used to avoid shearing the large molecules.

The DNA concentrations of such preparations measured by the diphenylamine reaction ranged from $\mathrm{I} 20$ to $300 \mu \mathrm{g} / \mathrm{ml}$. A molecular weight of about 400 million daltons was found for the major portion of this DNA, with more than $80 \%$ of the DNA having a molecular weight greater than 200 million.

Size of DNA. Size was calculated entirely from sedimentation properties in sucrose gradients. First, the sedimentation constant of the DNA was calculated from its position in a sucrose gradient by a variation of the technique described by Martin \& Ames (I96I). The molecular weight was then calculated from the sedimentation constant using the equation of Studier (1965). Molecular weights calculated by this method usually agree closely with those obtained by comparison with a standard DNA using the equation of Hershey, Burgi \& Ingraham (1963).

Recipient bacteria. Competence was developed by the method cited by Michalka \& Goodgal (I969). Also the relatively similar technique described by Catlin \& Tartagni (I969) was used, except that BHI (prepared within $24 \mathrm{~h}$ of use) was supplemented with Levinthal 
extract, and the concentration of NAD was lower $(0.5 \mu \mathrm{g} / \mathrm{ml}$ instead of $10 \mu \mathrm{g} / \mathrm{ml})$. This reduced the generation time of strain $\mathrm{RD}$ at $37^{\circ}$ from 28 to $32 \mathrm{~min}$; that of A8 was about $5 \mathrm{~min}$ longer. Further, the first aeration phase of cultivation was terminated at a lower bacterial density (extinction at $650 \mathrm{~nm}: 0.350$ to 0.400 in the $19 \mathrm{~mm}$ diam. tube). The remainder of the procedure was unchanged. Cultures were briefly chilled $\left(\mathrm{I}^{\circ}\right.$ to $\left.5^{\circ}\right)$ for 5 to $\mathrm{I} 5 \mathrm{~min}$ before use. Frozen and thawed cultures were not used.

Transformation tests. Chilled competent $\mathrm{A} 8$ recipient bacteria $(0 \cdot \mathrm{I} \mathrm{ml})$ were added to a warmed $\left(33^{\circ}\right.$ to $\left.35^{\circ}\right)$ solution of DNA in Levinthal broth $(2.9 \mathrm{ml})$. This reaction mixture was incubated for $3 \mathrm{~h}$ to permit phenotypic expression of antibiotic resistance. Alternatively, if transformations to Cap $\mathrm{b}$ and prototrophy only were to be determined, the incubation was terminated after 20 to $40 \mathrm{~min}$. The bacteria were chilled in an ice-bath, centrifuged at $4^{\circ}$, washed once and resuspended in chilled incomplete fluid medium. Appropriate concentrations of bacteria were spread over the surfaces of each kind of defined medium (with selected amino acids omitted or antibiotics added) for determination of iridescent transformants and total transformant colonies. In addition, the total number of colony-forming units $/ \mathrm{ml}$ (viable bacteria) present in the washed suspension was determined by plating a dilution in duplicate on complete defined agar and on Levinthal agar; equal numbers of colonies were recovered on these two media.

For some experiments, samples of the DNA-reaction mixture were taken after $30 \mathrm{~min}$. Viable bacteria and antibiotic-resistant transformants were assayed by inoculating appropriately diluted bacteria into melted infusion agar (BHI with NAD and haemin, or Levinthal agar). Phenotypic expression of antibiotic resistance occurred during incubation for 2 to $3 \mathrm{~h}$, after which measured volumes of antibiotic containing agar were added to the bottom layers of medium.

All surface-spread cultures were incubated at $35^{\circ}$ in the humidified atmosphere of closed plastic boxes containing moistened bibulous paper. The time of incubation of various media differed as required for the growth of prototrophic and antibiotic-resistant transformant colonies and especially for development and maintenance of colonial iridescence. Defined media lacking leucine and biotin were incubated at $35^{\circ}$ for less than $24 \mathrm{~h}$, whereas somewhat longer incubation (up to $42 \mathrm{~h}$ ) was required to obtain countable transformants on valine-free medium. Levinthal agar cultures of bacteria sampled from transformation reaction mixtures were incubated for a few hours at $35^{\circ}$ and were transferred to $30^{\circ}$ for incubation overnight. This was necessary because iridescence is a transient property of Cap b colonies which diminishes, during continued incubation, at a rate which depends upon the temperature and degree of crowding. When maximum iridescence was observed it could be maintained by holding the cultures at $5^{\circ}$ to $8^{\circ}$ for a day or two.

Transformant colonies were inspected for iridescence and were counted at $\times 9$ magnification with a stereo microscope and the special lighting arrangement previously described (Catlin, 1970). This enhanced the prismatic effect produced when a beam of tungsten light is directed upward obliquely through the colonies of capsulated bacteria cultivated on transparent medium. During examination of colonies, the acute angle of the light beam was varied by moving the substage mirror, and the culture plate was rotated by hand so that the colonies were illuminated from several directions one of which might enhance the iridescence. As they were counted, the colonies were punched or swept aside with a blunt needle.

Physical size of the capsulation locus. This was measured by a technique similar to that used for measuring the physical size of prophage HPI-cl (Bendler, 1968) and the physical separation of antibiotic markers (Bendler, 1968) and auxotrophic markers (Michalka \& Goodgal, 1969). 
Cap b MAP DNA was diluted and divided into four portions. One portion was left unsheared. A second portion was mildly sheared by pipetting it several times in a $0.2 \mathrm{ml}$ pipette. A third portion was sheared by squirting it vigorously through a no. 26 gauge needle. The last portion was sonicated for $60 \mathrm{~s}$ at $0^{\circ}$. These four portions were then remixed. About $0.2 \mathrm{ml}$ was layered (with care to avoid further shear) on to the top of a $5 \mathrm{ml}$ volume of a $5 \%$ to $20 \%$ sucrose gradient and spun in a Spinco SW 39 head for I $20 \mathrm{~min}$ at $35000 \mathrm{rev} . / \mathrm{min}$. Fifteen fractions were collected and the biological activity of each was assayed by adding $0 \cdot 1$ to $2.8 \mathrm{ml}$ of broth (BHI + NAD + haemin) together with $0.1 \mathrm{ml}$ of a competent culture of $\mathrm{A} 8$ recipients. After $30 \mathrm{~min}$ incubation at $34^{\circ}$ with slow rotation of the tubes, the bacteria were diluted and assayed in BHI agar for numbers of single transformants to capsulation (iridescent colonies) and to novobiocin resistance and double transformants to novobiocin and streptovaricin resistance.

The activity of the Cap b marker in each sucrose gradient fraction is taken to be the ratio of the number of iridescent transformants to the number of Nov-r transformants. The physical size of the cap $b$ locus is the size of the DNA in that fraction in which the biological activity of the iridescence marker has extrapolated to zero; this is analogous to the application of Michalka \& Goodgal (I969).

Some quantitative refinements of this technique were used (to be discussed in detail elsewhere). Briefly in a plot of the activity $v s$ the inverse of the donor molecular weight, a straight line is obtained which extrapolates through zero biological activity at the point corresponding to the inverse molecular weight of the cap b locus. This plot is not shown, but confirms the size determination given here. A second refinement employed in calculations reported here makes use of the fact that a straight line also is obtained by plotting two linkages from two different pairs of markers in the same gradient against each other (or plotting an activity against linkage). The extrapolation of this straight line back through the origin signifies that the activities and/or linkages involve DNA fragments having the same size.

\section{Cap $b$ transformation}

\section{RESULTS}

The immunofluorescence method used earlier for investigating genetic transformation of Haemophilus influenzae strain RD at the cellular level revealed that type b capsulation was expressed promptly but multiplication of the newly capsulated transformants was delayed (Catlin \& Tartagni, 1969). To investigate the delay, and attempt to overcome it, the effects of altering various growth conditions were systematically examined. Also, a system was devised for observing the iridescent colonies composed of capsulated transformant bacteria and distinguishing them from the more numerous non-iridescent colonies typical of the non-capsulated recipients. The resulting procedure (given in Methods) when applied to either recipient strain RD or A8 was effective in promoting multiplication of the Cap b transformants during incubation at $33^{\circ}$ of the transformation reaction broth. Infusion media supplemented with NAD and either haemin or Levinthal extract could be used, although the Cap b transformation frequencies were somewhat higher where Levinthal extract was used to fulfill the haeme requirement. Cap b transformants - in these experiments assayed as iridescent colonies were always fewer than antibiotic resistant transformants. In a representative experiment which used Levinthal-supplemented broth and agar, a competent population of A8 recipient bacteria was exposed at $33^{\circ}$ to I $\mu \mathrm{g}$ of Cap b MAP DNA $/ \mathrm{ml}$. Deoxyribonuclease was added at $20 \mathrm{~min}$, and a sample of the bacteria was taken at $23 \mathrm{~min}$. Suitable dilutions plated on agar gave the following results: $1 \cdot 7 \times 10^{8} / \mathrm{ml}$ viable bacteria $(\mathrm{V}), 2 \cdot 3 \times 10^{6} / \mathrm{ml}$ novobiocin- 
Table 2. Number of iridescent (Cap b) transformants among selected linked double transformants which span the mapped length of the Haemophilus influenzae chromosome*

\begin{tabular}{|c|c|c|c|c|c|c|}
\hline \multirow[b]{3}{*}{$\begin{array}{c}\text { Selected } \\
\text { linked markers }\end{array}$} & \multicolumn{6}{|c|}{ Transformant colonies (no./ml) } \\
\hline & \multicolumn{3}{|c|}{ 30-min sample $\dagger$} & \multicolumn{3}{|c|}{ I80-min sample } \\
\hline & $\begin{array}{l}\text { Iridescent } \\
\text { (I) }\end{array}$ & $\begin{array}{l}\text { Total } \\
\text { (T) }\end{array}$ & $\begin{array}{l}\text { Ratio } \\
\mathrm{I} / \mathrm{T}\end{array}$ & $\begin{array}{l}\text { Iridescent } \\
\text { (I) }\end{array}$ & $\begin{array}{l}\text { Total } \\
(\mathrm{T})\end{array}$ & $\begin{array}{l}\text { Ratio } \\
\mathrm{I} / \mathrm{T}\end{array}$ \\
\hline $\mathrm{Ala} \div \mathrm{Sva}-\mathrm{r}$ & . & . & . & 360 & 573200 & 0.0006 \\
\hline Sva-r Nov-r & . & . & . & 400 & 829800 & 0.0005 \\
\hline Nov-r Val ${ }^{+}$ & . & . & . & 20 & 55800 & 0.0004 \\
\hline $\mathrm{Val}^{+}$Lys $^{+}$ & . & . & . & 280 & 218000 & 0.0013 \\
\hline Lys $^{+}$Ery-r & . & . & . & 160 & 19780 & 0.0081 \\
\hline Ery-r Leu ${ }^{+}$ & . & . & . & I 20 & 23540 & $0.005 I$ \\
\hline $\mathrm{Leu}^{+}$only & 9600 & 588000 & 0.016 & 10000 & I 082000 & 0.0092 \\
\hline $\mathrm{Leu}^{+} \mathrm{Bio}^{+}$ & I I 000 & 34200 & 0.320 & 18000 & 83400 & 0.216 \\
\hline $\mathrm{Bio}^{-}$only & 72000 & 280800 & 0.260 & I 66000 & I 094000 & 0.152 \\
\hline $\mathrm{Bio}^{+} \mathrm{Pro}^{+}$ & 1320 & 5400 & 0.244 & I 620 & 14060 & 0.115 \\
\hline $\mathrm{Pro}^{+} \mathrm{Nal}-\mathrm{r}$ & . & . & . & 160 & 341200 & 0.0005 \\
\hline Nal-r Trp ${ }^{+}$ & . & . & . & $<20$ & 38000 & $<0.0005$ \\
\hline
\end{tabular}

* The transformation reaction broth (Levinthal) contained competent polyauxotrophic A8 bacteria and Cap b MAP DNA ( $\mu \mathrm{g} / \mathrm{ml}) ; 36^{\circ}$ incubation. Control broth: the same except the DNA was from a Cap b polyauxotrophic donor. Samples of bacteria were washed and suspensions were plated as described under Methods.

$\dagger$ Washed suspension contained $\mathrm{I} \cdot 2 \times 10^{8}$ viable bacteria $/ \mathrm{ml} ; 58000$ iridescent transformant colonies $/ \mathrm{ml}$ found on Levinthal agar.

$\ddagger$ Washed suspension contained $8.3 \times 10^{8}$ viable bacteria $/ \mathrm{ml} ; 170000$ iridescent transformant colonies $/ \mathrm{ml}$ found on Levinthal agar. No colonies appeared on defined media spread with washed bacteria from control broth.

resistant transformants (Nov-r $/ \mathrm{V}=0.014)$ and $3.8 \times 10^{4} / \mathrm{ml}$ iridescent transformants (Cap $\mathrm{b} / \mathrm{V}=0.0002$ ). During continued incubation of this transformation broth at $33^{\circ}$, the number of Cap b transformants $/ \mathrm{ml}$ (iridescent colonies) increased as follows: $8.1 \times 10^{4}$ at $76 \mathrm{~min}$, $\mathrm{I} \cdot 3 \times 10^{5}$ at $133 \mathrm{~min}, 3.0 \times 10^{5}$ at $186 \mathrm{~min}$ and $4.5 \times 10^{5}$ at $244 \mathrm{~min}$. This increase contrasts with the delayed multiplication of Cap $b$ transformants encountered under different conditions (Catlin \& Tartagni, I969).

\section{Map location of the cap $b$ locus}

The linear order of certain genes on the Haemophilus influenzae chromosome has been established (Michalka \& Goodgal, 1969). The Cap b marker was examined for its possible association with any of ten pairs of known linked markers. Competent auxotrophic bacteria, treated with DNA from the Cap b MAP donor, were washed and spread on defined agar medium which lacked selected growth compounds or contained antibiotics corresponding to the pairwise associations of the markers. Results obtained in a representative experiment are given in Table 2. Each medium was highly selective as shown by the absence of macrocolonies on plates spread with untreated bacteria or with bacteria from a control test of high molecular weight DNA from a Cap b transformant of A8 (the DNA which elicited transformation of strain RD, Table 3). Only doubly transformed bacteria were able to form macrocolonies on the two-factor selective media. Their number was related to the length of the DNA fragment and the distance separating the two markers involved. The map distance separating the leucine and biotin loci is less than that separating biotin and proline (Michalka \& Goodgal, 1969), therefore the number of $\mathrm{Leu}^{+} \mathrm{Bio}^{+}$transformants is expected 
Table 3. Distribution of non-selected nutritional markers among iridescent (Cap b) Haemophilus influenzae transformants*

\begin{tabular}{|c|c|c|c|c|c|}
\hline \multirow{3}{*}{$\begin{array}{c}\text { Recipient } \\
\text { bacteria }\end{array}$} & & \multicolumn{4}{|c|}{ Transformant colonies } \\
\hline & \multicolumn{4}{|c|}{ Phenotype } & \multirow{2}{*}{$\begin{array}{l}\text { No. } \\
\text { found }\end{array}$} \\
\hline & Val & Leu & Bio & Pro & \\
\hline \multirow[t]{6}{*}{ Strain $\mathbf{A} 8 \dagger$} & + & - & + & - & 3 \\
\hline & - & + & - & - & 5 \\
\hline & - & + & + & - & 9 \\
\hline & - & - & + & - & 63 \\
\hline & - & + & + & + & I \\
\hline & - & - & - & - & 15 \\
\hline \multirow[t]{4}{*}{ Strain RD $\ddagger$} & + & - & + & + & 4 \\
\hline & + & - & - & + & $\begin{array}{r}4 \\
28\end{array}$ \\
\hline & + & + & - & + & $\begin{array}{r}28 \\
4\end{array}$ \\
\hline & + & + & + & + & 4 \\
\hline
\end{tabular}

* Iridescent colonies typical of Cap b transformants were picked from Levinthal agar, isolated in pure culture and examined for type $b$ antigen. Their nutritional requirements were determined by streaking diluted bacterial suspensions on plates of defined agar which contained or lacked valine or leucine or biotin or proline. $+=$ Growth occurred in the absence of added compound; $-=$ growth was dependent on its addition.

$+\mathrm{Cap}^{-} \mathrm{Val}^{-} \mathrm{Leu}^{-} \mathrm{Bio}^{-}$Pro-bacteria treated with DNA for $\mathrm{Cap}^{+} \mathrm{Val}^{+} \mathrm{Leu}^{+} \mathrm{Bio}^{+} \mathrm{Pro}^{+}$donor; 96 iridescent transformants tested.

$\ddagger \mathrm{Cap}^{-} \mathrm{Val}^{+} \mathrm{Leu}^{+} \mathrm{Bio}^{+} \mathrm{Pro}^{+}$bacteria treated with DNA from $\mathrm{Cap}^{+} \mathrm{Val}^{-} \mathrm{Leu}^{-} \mathrm{Bio}^{-} \mathrm{Pro}^{-}$donor; 40 iridescent transformants tested.

to be greater than $\mathrm{Bio}^{+} \mathrm{Pro}^{+}$. Iridescent colonies represented transformants which had received at least three markers. The ratio of iridescent to linked double transformants was high only in that region of the genetic map close to the biotin locus. Results from four experiments of this kind were in close agreement, and clearly indicated a close association between cap $b$ and bio-r 50 loci.

Two approaches were used to establish that the co-transformation of the two properties represented true linkage. One was to determine the fraction of doubly transformed to singly transformed bacteria in tests of a recipient $\mathrm{A} 8$ population with different concentrations of DNA from the Cap b MAP donor. If $c a p b$ and biotin loci are close together on the strand of transforming DNA, the probability of joint transfer will be independent of the concentration of DNA but will be a function of the number of single transformations (Goodgal, $196 \mathrm{I}$ ). Thus, the ratio of iridescent $\left(\mathrm{Cap} \mathrm{b} \mathrm{Bio}^{+}\right.$) transformants to total $\mathrm{Bio}^{+}$transformants recovered on biotin-free medium should be the same although the transformation frequencies will decline with reduction of DNA concentration. This expectation was realized, and the ratios $\left(\mathrm{Cap} \mathrm{b} \mathrm{Bio}^{+} / \mathrm{Bio}^{+}\right)$found in one experiment were $0 . \mathrm{I} 6,0 . \mathrm{I} 4,0.2 \mathrm{I}$ and 0.17 following treatment for $30 \mathrm{~min}$ with $\mathrm{IO}^{-1}, \mathrm{IO}^{-2}, \mathrm{IO}^{-3}, \mathrm{IO}^{-4} \mu \mathrm{g}$ of $\mathrm{DNA} / \mathrm{ml}$, respectively. The bacteria treated with $\mathrm{I}^{-4} \mu \mathrm{g}$ of DNA$/ \mathrm{ml}\left(30 \mathrm{~min} 33^{\circ}\right)$ followed by washing and plating on biotin-free agar yielded only $240 \mathrm{Bio}^{+}$transformants $/ \mathrm{ml}$, whereas treatment with $10^{-2} \mu \mathrm{g}$ of DNA $/ \mathrm{ml}$ yielded (per $\mathrm{ml}$ ) 6400 iridescent colonies among 46800 total $\mathrm{Bio}^{+}$transformants $\left(5^{\circ} \mathrm{O} \times \mathrm{IO}^{7}\right.$ viable bacteria in this washed suspension).

The second approach to the question of linkage was to examine the patterns of growth requirements of iridescent transformant colonies picked from Levinthal agar, i.e. with no selection for nutritional markers. Of $96 \mathrm{Cap} b$ transformants obtained from the auxotrophic recipient $\mathrm{A} 8$ by treatment with DNA from the Cap $\mathrm{b}$ MAP donor, 76 were biotin-non- 


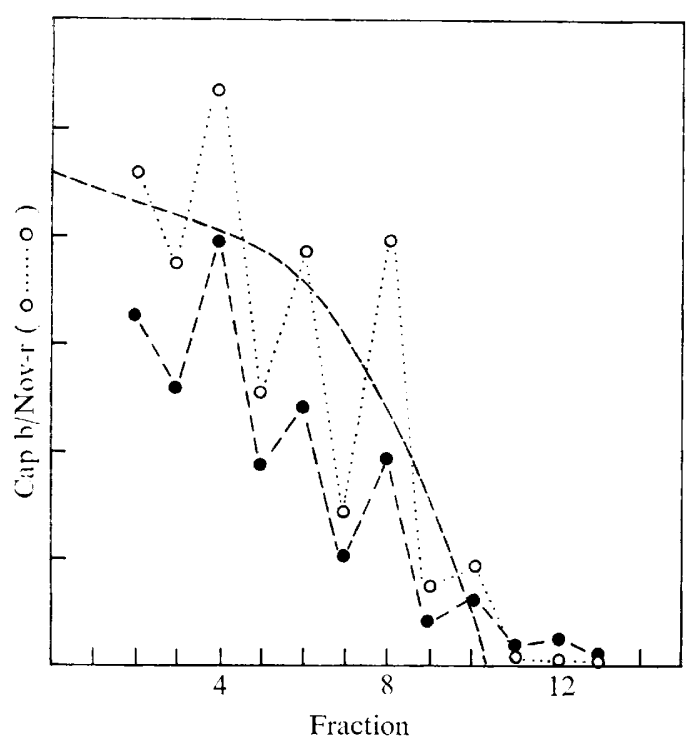

Fig. I

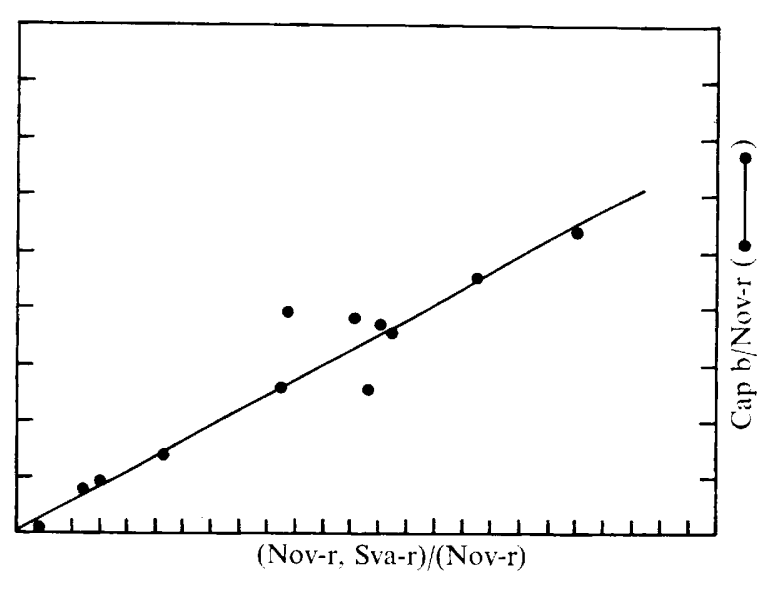

Fig. 2

Fig. I. Transforming activities of sheared Cap b MAP DNA in fractions obtained following centrifugation of a sucrose gradient, as described in Methods. Data are plotted as ratios of numbers of transformant colonies: $\bigcirc \cdots \cdots$, Cap b (iridescent)/novobiocin-resistant; ---0 , novobiocin-streptovaricin-resistant (double transformants)/novobiocin-resistant (single transformants). The smooth dashed line without points represents the theoretical activity of Cap b (iridescent colony) transformation which requires a 30 to 35 million dalton portion of DNA which is linearly integrated into the bacterial genome.

Fig. 2. Cap $b$ transforming activity plotted against the linkages for novobiocin-streptovaricin resistence in the same sucrose gradient fraction of DNA. The points fall, for the most part, on a straight line which intercepts the origin; this indicates that Cap $b$ transformation requires information spread out over a region of DNA having a length similar to the length of DNA between the Nov-r and Sva-r markers.

requiring (Table 3). Precautions were taken to reduce the likelihood that the iridescent colonies picked for testing might represent progeny of only a few transformants. These 96 colonies were obtained from seven different experiments involving 20 separate bacteriaDNA reaction mixtures. Samples were plated on Levinthal agar usually within $\mathrm{I} h$ of initiating the reaction. Furthermore, 44 of these transformants were obtained in tests with concentrations of DNA of $10^{-2} \mu \mathrm{g} / \mathrm{ml}$ or less to minimize the chance of having the two markers introduced on two separate DNA molecules. The valine marker, which is distant from biotin, served as a control to indicate the fraction of Cap $b$ transformants which received an unlinked nutritional marker. In reciprocal transformation tests DNA from one of the Cap $b$ transformants of $\mathrm{A} 8$ which had remained auxotrophic was used to treat non-capsulated prototrophic bacteria. Of the 40 iridescent transformants examined (strain RD, Table 3 ) $80 \%$ were biotin-requiring. Taken together, the numbers of both kinds of recipients which received the two markers jointly indicate approximately $80 \%$ linkage between cap $b$ and bio. Cap $b$ is much less closely linked to the leucine locus.

The discrepancy between linkage values calculated from the ratios $\mathrm{Cap} \mathrm{b} \mathrm{Bio}^{+} / \mathrm{Bio}^{+}$and $\mathrm{Cap} \mathrm{b} \mathrm{Bio}+/ \mathrm{Cap} \mathrm{b}$ is related to the fact that $\mathrm{Cap} \mathrm{b}$ transformants are relatively less numerous than $\mathrm{Bio}^{+}$transformants. 


\section{Size of the cap b locus}

The size of the smallest fragment of Cap b MAP DNA which could elicit transformation of competent A8 bacteria was measured. A heterogeneous mixture of fragments of DNA sheared to different lengths was resolved into various size fractions by sedimentation in a sucrose gradient. Each gradient fraction was assayed by transformation; the numbers of iridescent colonies, colonies resistant to novobiocin, and colonies resistant to both novobiocin and streptovaricin were counted. These data are plotted in Fig. I. In Fig. 2 the same data are plotted 'parametrically' to eliminate the parameter 'gradient fraction'. In this way the errors due to convective disturbances in the gradient and the inaccuracies of novobiocin-resistant colony counts tend to be eliminated. The scatter of the data is much reduced compared to Fig. I. In a region of the gradient corresponding to a size of DNA which was abundantly represented (as determined by the number of single transformants to novobiocin-resistance alone) the Cap $b$ (iridescence) transforming activity and the linkage of novobiocin and streptovaricin resistances both extrapolated to zero. The results show that the segment of DNA which is required for Cap $b$ transformation is equal in size to the portion of DNA which carries the linked nov-sva markers. The size of the segment of DNA between the nov and sva markers was previously determined to be about 33 million daltons (Bendler, 1968). We conclude, therefore, that the genes essential for Cap b transformation extend over a segment of DNA having a molecular weight of about 33 million daltons.

\section{DISCUSSION}

Capsule production was one of the dispensable bacterial functions which Jacob, Schaeffer $\&$ Wollman (1960) suggested might be episomal. The frequent appearance of non-capsulated bacteria in cultures of type b capsulated Haemophilus influenzae and their apparent lack of spontaneous reversion (Catlin, 1970) accords with the idea that the cap b genes might be located on a DNA segment which is extrachromosomal, replicates autonomously and may be lost. The work reported here bears directly on this problem. The correlation data (Fig. 2) obtained with the Cap b MAP DNA indicate that the genes for capsular transformation are linearly integrated in a 33 million dalton segment of chromosomal DNA, and are not primarily present as an extrachromosomal element. This evidence, however, does not rule out the possibility of extrachromosomal cap $b$ as a minor fraction of the $c a p b$ loci represented in this DNA preparation or as a major fraction in DNA from strains recently isolated from clinical sources.

Our estimate of the length of the DNA segment required for Cap $b$ transformation involved counts of antibiotic resistant colonies on selective media and iridescent colonies on non-selective medium. As detection of the latter is less efficient, some Cap b transformants elicited by each of the gradient fractions probably were overlooked. However, this should have been a constant proportion throughout the gradient as the number of DNA-treated recipient bacteria plated was the same for all fractions. A great advantage of the technique illustrated in Fig. 2 is that the omission of any constant proportion of $\mathrm{Cap} \mathrm{b}$ or antibiotic resistant colonies would only influence the slope of the line and would not influence the extrapolation of the line through the origin. Therefore, the estimate of molecular size would not be affected. Other kinds of errors giving rise to non-proportional omissions of either Cap b or antibiotic resistant colonies would result in curvature of the line.

The physical experiment can supply no direct information concerning the distribution of $c a p b$ genes within the required segment of DNA. Although in theory only two point mutations 
separated by 33 million daltons need be involved in Cap b transformation, it is likely that a number of new genes are encoded within the 33 million segment. Studies of the biosynthesis of pneumococcal capsular polysaccharides have revealed not only the requirement for a number of enzymes - and therefore genes - but for different kinds of enzymes (Mäkelä \& Stocker, 1969). The whole 33 million segment of Haemophilus influenzae DNA could code for possibly 60 or more proteins, but it seems unlikely that all of them would be required for capsule production. Possibly the DNA segment required for Cap $b$ transformation is interspersed with genetic loci unrelated to capsulation. A further possibility is that the $c a p b$ genes are included in a region of the chromosome which is present in the DNA of noncapsulated bacteria derived from type $b$ strains but lacking in the non-capsulated recipient strain RD (derived from a type d organism). In this case the minimum size of the donor DNA segment necessary for Cap $b$ transformation would depend on the recipient, being smaller with a more closely related recipient which possesses needed regions of homology. Accordingly, strain RD could be considered to have the equivalent of a deletion of the region which extends beyond the cap $b$ locus, and which would have to be included in the donor piece so that a region of homology might be reached at either end of the donor segment.

The overall results indicate that the information required for type $b$ capsular transformation of strain RD occupies an extensive segment of DNA in a region of the chromosome very close to the bio-r 50 marker. This proximity to an auxotrophic marker will permit selective methods to be applied in transformation studies of mutant cap $b$ genes.

This investigation was supported by U.S. Public Health Service research grants AI-02353 (to B.W.C.) and AI-04557 (to S.H.G.) from the National Institute of Allergy and Infectious Diseases.

\section{REFERENCES}

AleXander, H. E. \& Leidy, G. (195I). Determination of inherited traits of $H$. influenzae by desoxyribonucleic acid fractions isolated from type-specific cells. Journal of Experimental Medicine 93, 345-359.

AleXANDER, H. E., Leidy, G. \& HahN, E. (1954). Studies on the nature of Hemophilus influenzae cells susceptible to heritable changes by desoxyribonucleic acids. Journal of Experimental Medicine 99, 505-533.

BENDLER, J. W., III. (I968). Size of prophage HPI-cI and amount of DNA between genetic markers in Haemophilus influenzae. Doctoral Dissertation, The Johns Hopkins University, Baltimore, Maryland.

Berns, K. I. \& Thomas, C. A., Jun. (I965). Isolation of high molecular weight DNA from Hemophilus influenzae. Journal of Molecular Biology Ir, 476-490.

CATLin, B. W. (1970). Haemophilus influenzae in cultures of cerebrospinal fluid: noncapsulated variants typable by immunofluorescence. American Journal of Diseases of Children 120, 203-210.

CATLIN, B. W. \& TARTAGni, V. R. (I969). Delayed multiplication of newly capsulated transformants of Haemophilus influenzae detected by immunofluorescence. Journal of General Microbiology 56, 387-40I.

Goodgat, S. H. (1961). Studies on transformations of Hemophilus influenzae IV. Linked and unlinked transformations. Journal of General Physiology 45, 205-228.

Herriott, R. M., Meyer, E. Y., Vogt, M. \& Modan, M. (1970). Defined medium for growth of Haemophilus influenzae. Journal of Bacteriology ror, $513-516$.

Hershey, A. D., Burgi, E. \& InGraham, L. (1963). Cohesion of DNA molecules isolated from phage lambda. Proceedings of the National Academy of Sciences of the United States of America 49, 748-755.

JACOB, F., SChaEFfer, P. \& Wollman, E. L. (1960). Episomic elements in bacteria. Symposium of the Society for General Microbiology 10, 67-9I.

Leidy, G., Hahn, E., Zamenhof, S. \& Alexander, H. E. (1960). Biochemical aspects of virulence of Hemophilus influenzae. Annals of the New York Academy of Sciences 88, I 195-I $20 \mathrm{I}$.

MÄKelä, P. H. \& STOCKER, B. A. D. (1969). Genetics of polysaccharide biosynthesis. Annual Review of Genetics 3, 29I-322. 
MARTIN, R. G. \& AMES, B. N. (I96I). A method for determining the sedimentation behaviour of enzymes: application to protein mixtures. Journal of Biological Chemistry 236, 1372-1379.

MichalkA, J. \& Goodgal, S. H. (1969). Genetic and physical map of the chromosome of Hemophilus influenzae. Journal of Molecular Biology 45, 407-421.

PItTMAN, M. (193I). Variation and type specificity in the bacterial species Hemophilus influenzae. Journal of Experimental Medicine 53, 471-49I.

RosenberG, E. \& ZAMENHOF, S. (I96I). Further studies on polyribophosphate. Journal of Biological Chemistry 236, 2845-2849.

STUDIER, F. W. (1965). Sedimentation studies of the size and shape of DNA. Journal of Molecular Biology Ir, 373-390.

TURK, D. C. \& MAY, J. R. (1967). Haemophilus Influenzae: Its Clinical Importance. London: English Universities Press. 